\title{
MECHANICAL PROPERTIES OF A BAINITIC STEEL PRODUCIBLE BY HOT ROLLING
}

\begin{abstract}
A carbide-free bainitic microstructure is suitable for achieving a combination of ultra high strength and high ductility. In this work, a steel containing nominally $0.34 \mathrm{C}-2 \mathrm{Mn}-1.5 \mathrm{Si}-1 \mathrm{Cr}(\mathrm{wt} . \%)$ was produced via industrial hot rolling and laboratory heat treatments. The austenitization $\left(900^{\circ} \mathrm{C}, 30 \mathrm{~min}\right.$.) and austempering $\left(300-400^{\circ} \mathrm{C}, 3 \mathrm{~h}\right)$ treatments were done in salt bath furnaces. The austempering treatments were designed to approximately simulate the coiling step, following hot rolling and run-out-table cooling, when the bainitic transformation would take place and certain amount of austenite would be stabilized due to suppression of carbide precipitation. The microstructures and various mechanical properties (tensile properties, bendability, flangeability, and room and subzero temperature impact toughness) relevant for applications were characterized. It was found that the mechanical properties were highly dependent on the stability of the retained austenite, presence of martensite in the microstructure and the size of the microstructural constituents. The highest amount of retained austenite $(\sim 27 \mathrm{wt} . \%)$ was obtained in the sample austempered at $375^{\circ} \mathrm{C}$ but due to lower austenite stability and coarser overall microstructure, the sample exhibited lower tensile ductility, bendability, flangeability and impact toughness. The sample austempered at $400^{\circ} \mathrm{C}$ also showed poor properties due to the presence of initial martensite and coarse microstructure. The best combination of mechanical properties was achieved for the samples austempered at $325-350^{\circ} \mathrm{C}$ with a lower amount of retained austenite but with the highest mechanical stability.
\end{abstract}

Keywords: Carbide-Free Bainite; Retained Austenite; Hot Rolling; Mechanical Properties

\section{Introduction}

The demand of lightweight fuel-efficient materials from the automotive industry drives the steel producers to develop high strength steels with adequate formability. A carbide-free bainitic (CFB) or bainitic ferrite microstructure is known to enhance the ductility of steels due to the absence of brittle cementite particles. In addition, a CFB microstructure can guarantee also an ultra high strength due to the strengthening from ultrafine $(<100 \mathrm{~nm})$ bainitic ferrite sheaves as well as high dislocation density inherent to the bainitic phase transformation [1-3]. On the other hand, retained austenite, when present in sufficient amount, is known to enhance the ductility in advanced high strength steels (AHSS) through transformation-induced plasticity (TRIP) effect [4-6].

In this work a carbide-free bainitic steel with high amount of retained austenite was developed to achieve a combination of ultra high strength $(>1400 \mathrm{MPa})$ with high ductility (total elongation $>20 \%$ )._The steel was designed to produce in hot rolled condition so that the bainitic transformation can take place during the slow cooling of hot rolled coils. Various mechanical and formability properties, relevant for automotive applications, were evaluated in heat treated conditions and the microstructureproperty-processing relationships were established. In particular, the effects of isothermal bainitic transformation at different temperatures on the microstructure and various mechanical and formability properties were investigated. The isothermal bainitic transformation at different austempering temperatures for long time (3 hours) accomplished in this work can be regarded as coiling simulation of hot rolled strips where a slow cooling allowing long time for transformation is employed.

\section{Alloy design}

The alloy for the current study was designed by thermodynamic calculations using ThermoCalc software. To produce the carbide-free bainitic steel in hot rolled condition with ultra high strength level and high ductility, the designed alloy must meet a few criteria:

(i) the alloy must have sufficient hardenability to avoid diffusional ferritic or pearlitic transformation during/after hot rolling i.e. during run-out-table (ROT) cooling,

(ii) the alloy must have a low bainitic transformation start temperature $\left(\mathrm{B}_{\mathrm{s}}\right)$ to ensure formation of fine bainite, and a low martensitic transformation start temperature $\left(\mathrm{M}_{\mathrm{s}}\right)$ to avoid/minimize martensite formation,

\footnotetext{
* TATA STEEL, WENCKEBACHSTRAAT 1, 1970 CA IJMUIDEN, THE NETHERLANDS 
(iii) the alloy must have a sufficient temperature gap between $B_{s}$ and $M_{s}$ to allow sufficient bainitic transformation, and

(iv) the alloy chemistry must allow sufficient carbon enrichment in austenite during bainitic transformation to stabilize large amount of retained austenite at room temperature.

Considering the above criteria, the process for producing hot rolled bainitic steel is shown schematically in Fig. 1. The following major elements were considered for designing the alloy based on their known metallurgical effects: C, Mn, Si, Cr. All these four elements delay the high temperature diffusional transformations in steel [7], avoiding ferrite and pearlite formation. These elements also lower the $\mathrm{B}_{\mathrm{s}}$ and $\mathrm{M}_{\mathrm{s}}$ of the steel [8-11] meeting criterion (ii) above. However, their effects on $M_{s}$ have been reported to be stronger than that on $\mathrm{B}_{\mathrm{s}}$, and therefore a sufficient temperature gap between $B_{s}$ and $M_{s}$ is expected. To ensure that the criterion (iv) is met, sufficient amount of Si was added $(\sim 1.5$ wt.\%). Silicon has been reported to prohibit carbide formation during bainitic transformation, and as a result the rejected $\mathrm{C}$ from bainitic ferrite gets enriched in austenite increasing its stability. This ensures that a high amount of austenite remains untransformed and is retained at room temperature. Further details of alloy design can be found elsewhere [12]

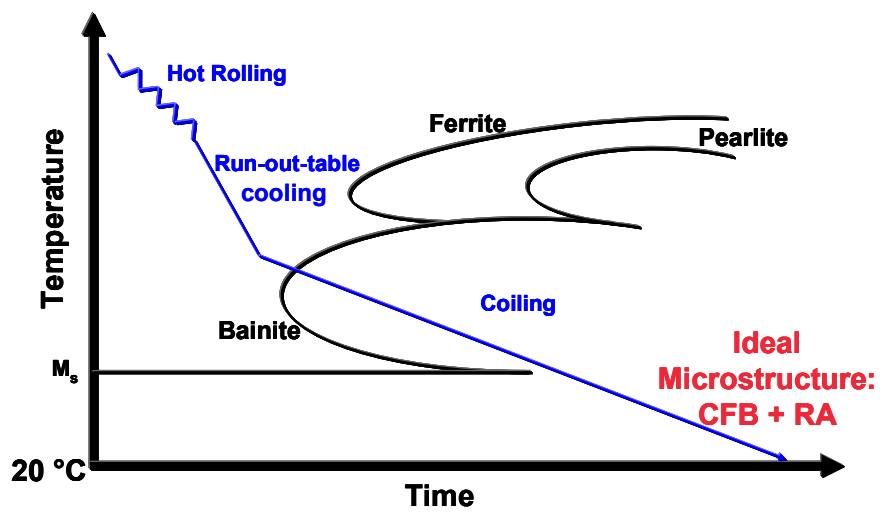

Fig. 1. Schematic representation of the hot rolling process route superimposed on the continuous cooling transformation diagram of the steel to produce a predominantly carbide-free bainitic (CFB) microstructure with considerable amount of retained austenite (RA)

\section{Experimental details}

\subsection{Materials manufacturing and heat treatments}

The nominal chemistry of the steels is given in Table 1 . The material for this study was made in two different methods. Pilot scale heat of $\sim 5.5$ tonne was made at Tata Steel facilities in Teesside, UK and then hot rolled to $3 \mathrm{~mm}$ thickness at another Tata Steel facility in Brinsworth, UK with the following process variables: slab reheating temperature $=1250^{\circ} \mathrm{C}$, finish rolling temperature $=950^{\circ} \mathrm{C}$, ROT cooling rate $=20^{\circ} \mathrm{C} / \mathrm{s}$ and coiling temperature $=410^{\circ} \mathrm{C}$. This material was used for most of the heat treatments and characterization. Laboratory scale $(\sim 25 \mathrm{~kg})$ ingots were also made and hot rolled to a thickness of $12 \mathrm{~mm}$ using the same process variables. This laboratory-rolled thicker material was used for Charpy impact tests that require $10 \mathrm{~mm} \times 10 \mathrm{~mm}$ cross section of the specimens.

TABLE 1

Nominal compositions of the investigated pilot scale and laboratory scale steels in wt.\%

\begin{tabular}{|c|c|c|c|c|c|c|c|}
\hline \hline $\mathbf{C}$ & $\mathbf{M n}$ & $\mathbf{S i}$ & $\mathbf{C r}$ & $\mathbf{T i}$ & $\mathbf{A l}$ & $\mathbf{N}$ & $\mathbf{F e}$ \\
\hline 0.34 & 1.94 & 1.65 & 1.07 & 0.03 & 0.011 & 0.0063 & Balance \\
\hline
\end{tabular}

Strips of $220 \mathrm{~mm} \times 100 \mathrm{~mm}$ were cut and heat treated in salt baths for austenitization and austempering. The strips were austenitized in high-temperature salt bath at $900^{\circ} \mathrm{C}$ for $30 \mathrm{~min}$. and then transferred to an adjacent low-temperature salt bath quickly (within $\sim 3 \mathrm{~s}$ ), and austempered isochronally for $3 \mathrm{~h}$ at the temperatures of $300,325,350,375$ and $400^{\circ} \mathrm{C}$ for the bainitic transformation to take place. Then, the samples were cooled in air to room temperature. In these laboratory simulations, the austenitization can be regarded as finish rolling temperature, and considering the long cooling time available during coil cooling, the treatment for $3 \mathrm{~h}$ in the low-temperature salt bath can be considered to bring equivalent effects as coiling in industrial condition. The quick transfer of the samples from high-temperature salt bath to low-temperature salt bath ensures a fast cooling, at par with a fast ROT cooling $\left(>20^{\circ} \mathrm{C} / \mathrm{s}\right)$, from austenitization temperature to the austempering temperature avoiding formation of ferrite and/or pearlite.

\subsection{Characterization}

All the specimens for the characterization of microstructure, mechanical properties and formability were prepared from the variously heat treated strips of $3 \mathrm{~mm}$ thick pilot scale material. Only the specimens for Charpy impact tests were extracted from $12 \mathrm{~mm}$ thick laboratory material in two heat treated conditions as described later.

ASTM E-8 sub-sized tensile specimens were prepared with the gauge length along the rolling direction and room temperature tensile tests were done with an initial strain rate of $2.5 \times 10^{-4}$ $\mathrm{s}^{-1}$. Bending specimens of $40 \mathrm{~mm}$ length and $30 \mathrm{~mm}$ width were prepared, and three-point bending tests were done following the standard of the Association of German Automobile Industries (VDA 238-100). During the tests, the bending axis (along the width of $30 \mathrm{~mm}$ ) was both parallel and perpendicular to the rolling direction. The specimens with bending axis parallel to the rolling direction are denoted as 'longitudinal' specimens and perpendicular to the rolling direction as 'transverse' specimens. The flangeability of the steel was evaluated by hole expansion tests. Specimens of $90 \mathrm{~mm} \times 90 \mathrm{~mm}$ were cut and then a hole of $10 \mathrm{~mm}$ diameter was punched in the middle of the specimen, and the hole expansion tests were carried out according to ISO/TS 
16630:2003(E) standard. The hole expansion ratio, HER (expansion of the initial diameter of the hole / initial diameter of the hole) $\times 100 \%$ ) was calculated from the measured data. Three specimens in each condition for each of the mechanical tests were examined and the average of the three measured values is reported.

Standard Charpy V-notch (CVN) specimens with dimensions, $55 \mathrm{~mm} \times 10 \mathrm{~mm} \times 10 \mathrm{~mm}$, following ASTM A370 standard, were machined from two austempering conditions ( 350 and $375^{\circ} \mathrm{C}$ ). The length of the specimens was parallel to the rolling direction and the root of the notch was placed on the plane of rolling and transverse directions. The surface finish requirements of the Charpy specimens were also maintained following the ASTM A370 standard. Charpy impact tests were done in an instrumented Charpy machine at the following temperatures, 20, $-20,-40,-60$ and $-80^{\circ} \mathrm{C}$. Three specimens were tested for each condition and the average impact energy values are reported.

The microstructures were characterized by using light optical microscopy (LOM) and X-ray diffraction (XRD). A selected sample austempered at $350^{\circ} \mathrm{C}$ was also subjected to transmission electron microscopic (TEM) examination using bright field. The samples for LOM were prepared from the thickness plane (i.e. the plane containing rolling and normal directions) by standard metallographic polishing, etched with LePera ( 1 vol.\% aqueous solution of sodium metabisulfite and 4 vol.\% picric acid in ethyl alcohol) reagent for $120 \mathrm{~s}$, and then the microstructures were recorded from the mid-thickness area. Room temperature XRD patterns over a $2 \theta$ range of $45-165^{\circ}(\theta=$ angle of diffraction $)$ were recorded from the quarter thickness of the heat treated samples in a Panalytical Xpert PRO diffractometer with $\mathrm{Co}-\mathrm{K}_{\alpha}$ radiation at a scan rate of $0.017^{\circ} \mathrm{s}^{-1}$. The austenite and martensite (from the peak splits at ferrite diffraction angles) phase contents were estimated by Rietveld analysis [13] of the XRD patterns using Bruker Topas software package [14].

To determine the mechanical stability of retained austenite in the final heat treated conditions interrupted tensile tests were conducted. The samples austempered at 325,350 and $375^{\circ} \mathrm{C}$ were strained in tensile tests to predetermined strain levels in the uniform elongation regime, and then austenite contents were measured from the gauge section by the XRD method. The tensile tests were interrupted at engineering strains of 2, 5, 10 and $15 \%$ in the uniform strain regime; the exact values for a particular sample being dependent on the elongation exhibited by the sample.

\section{Results and discussion}

\subsection{Microstructure}

The LOM micrographs of the material with colour etching by LePera reagent are shown in Fig. 2 for all the austempering conditions. From the overview, it can be observed that for austempering at lower temperatures $\left(300-350^{\circ} \mathrm{C}\right)$ a relatively finer microstructure formed than for austempering at higher temperatures of 375 and $400^{\circ} \mathrm{C}$. In these microstructures, from the colour variations, different phases can be identified. The bluish areas are bainitic ferrite and the martensite-austenite (M-A) constituents are represented by the whitish and brownish areas. The etch effect of M-A constituents is different in the samples austempered at 375 and $400^{\circ} \mathrm{C}$ than the other samples. In these
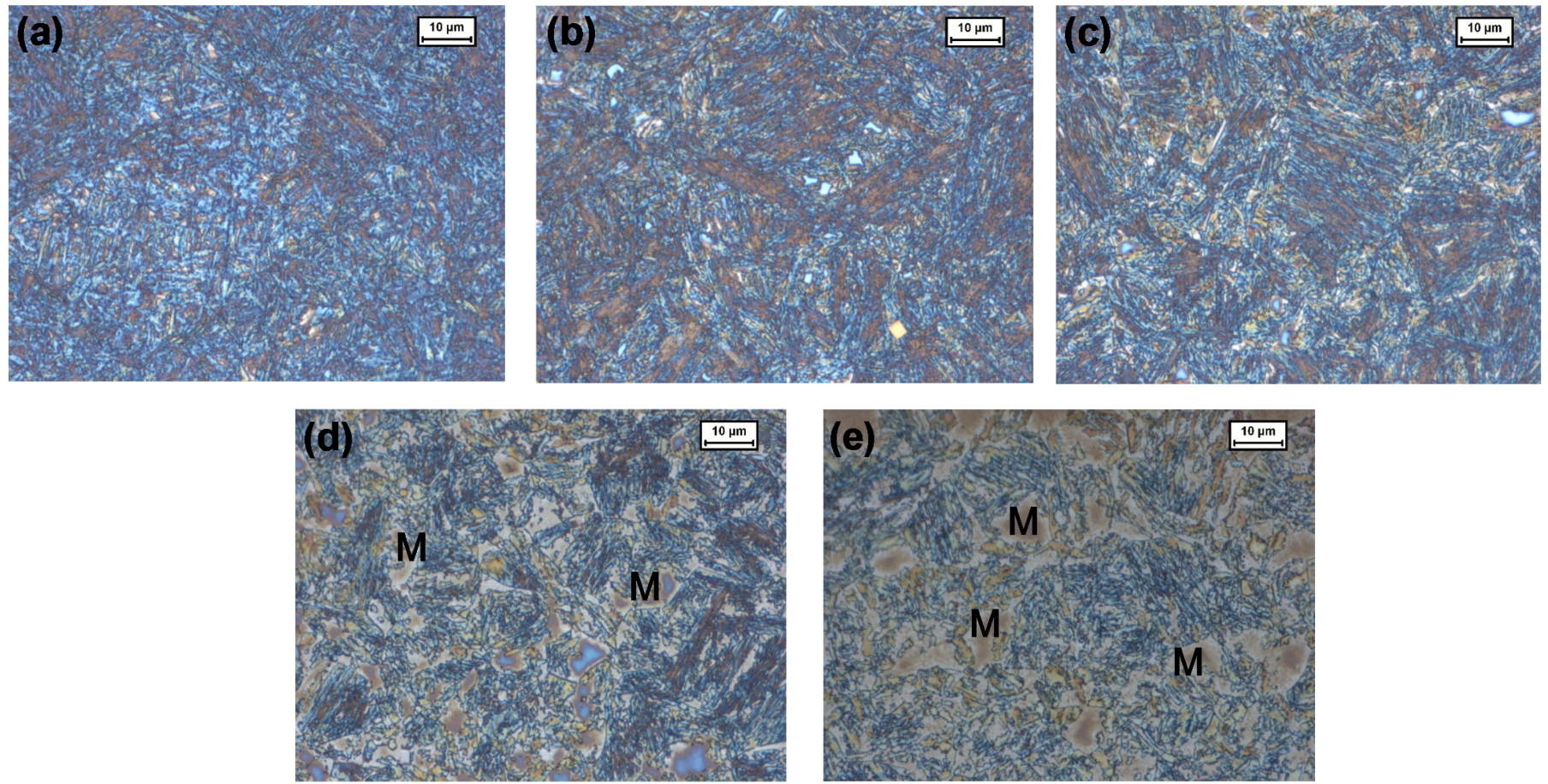

Fig. 2. Light optical microstructures of the steel austempered at different temperatures for 3 hours: (a) 300 (b) 325 (c) 350 (d) 375 , and (d) $400^{\circ} \mathrm{C}$. Samples were taken from the plane containing rolling and normal directions and etched with LePera reagent (for the colours, please refer to the online version of the article) 
two samples isothermally held at higher temperatures, a gradient in etching is observed in the M-A areas. This can be due to gradient of carbon (and also possibly $\mathrm{Mn}$ ) concentration present in austenite as reported in literature $[15,16]$. As for example, the lower carbon areas of austenite will be less stable and thus transform to martensite during cooling to room temperature after austempering. The dark areas inside the M-A islands in the samples heat treated at 375 and $400^{\circ} \mathrm{C}$ are presumably martensitic areas. Furthermore, the M-A islands are very coarse and blocky in nature in the samples austempered at 375 and $400^{\circ} \mathrm{C}$. The representative TEM bright field image for the sample austempered at $350^{\circ} \mathrm{C}$ is shown in Fig. 3. It reveals a refined microstructure with a width of bainitic ferrite in the range of 300-500 $\mathrm{nm}$ (the white phase) and retained austenite mostly in the form of films within the bainitic ferrite plates (the dark phase), with very small amount of blocky type of retained austenite.

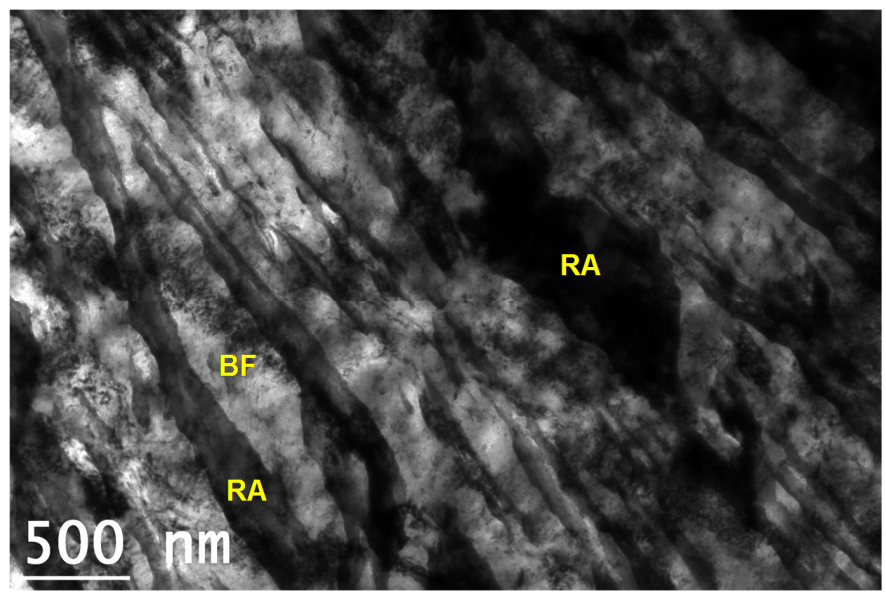

Fig. 3. Bright field TEM micrograph of the steel austempered at $350^{\circ} \mathrm{C}$ showing fine plates of bainitic ferrite and presence of both coarse and fine (blocky and filmy types) retained austenite

The amounts of retained austenite (RA) and martensite

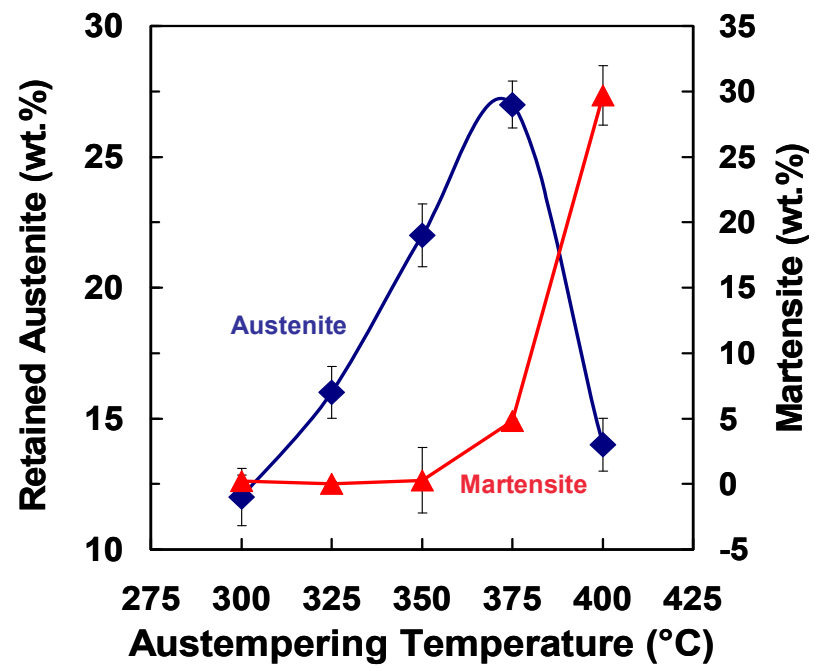

Fig. 4. Retained austenite and martensite contents as estimated from XRD data of the studied steel plotted against austempering temperature as estimated from XRD measurements are plotted in Fig. 4 as a function of isothermal holding temperature for austempering. The RA content initially increased with austempering temperature exhibiting a maxima for bainitic transformation at $375^{\circ} \mathrm{C}$; however after that the RA content decreased for holding at $400^{\circ} \mathrm{C}$. The martensite contents, plotted in the second vertical axis, indicates that almost no martensite formed in the steel for low austempering temperatures $\left(300-350^{\circ} \mathrm{C}\right)$; however about 5 wt. $\%$ martensite formed for austempering at $375^{\circ} \mathrm{C}$ and the martensite content increased to as high as $\sim 30 \mathrm{wt} . \%$ for austempering at $400^{\circ} \mathrm{C}$. Moreover, it can be inferred from Fig. 4 that the bainite content in the material decreased with increasing austempering temperature, assuming the microstructure after each of the heat treatments consists of bainite, retained austenite and martensite.

The observed microstructure evolution above can be interpreted in the following way. During austempering of the present steel, bainitic transformation takes place and some austenite remains. During transformation of austenite to bainite, the rejected $\mathrm{C}$ from bainitic ferrite becomes enriched in the untransformed austenite due to the presence of $\mathrm{Si}$ in the steel $[17,18]$. The untransformed austenite will transform to martensite or get stabilized during subsequent cooling to room temperature depending on its $\mathrm{C}$ content. With an increasing austempering temperature the $\mathrm{C}$ content that the austenite can retain decreases. This makes the untransformed austenite chemically less stable during subsequent cooling to room temperature. On the other hand, with austempering temperature the amount of bainite transformation expected follows a "C-curve" similar to the continuous cooling transformation (CCT) diagram for the well-known reasons of temperature effects on the nucleation and growth of bainite plates. Therefore, with austempering temperature the balance of the untransformed austenite content present in the steel and its chemical stability determined by $\mathrm{C}$ content will decide the retained austenite content at room temperature.

\subsection{Austenite stability}

The actual RA contents and the changes in RA content with strains estimated from the XRD data of the specimens from interrupted tensile tests are presented in Fig. 5. For the changes in RA contents in Fig. 5b, the change in RA contents estimated for various strain levels were normalized by the initial RA contents for $0 \%$ strain (the undeformed sample) for the specific heat treatment condition to calculate the 'austenite transformation ratio' (= change in retained austenite content at a specific strain / retained austenite content in undeformed condition). The value of the austenite transformation ratio should vary from 0 to 1 for a particular condition; and a transformation ratio of ' 0 ' indicates no austenite transformation whereas a transformation ratio of ' 1 ' signifies all austenite transformed to martensite via TRIP mechanism.

Figure 5a shows that the RA content for $375^{\circ} \mathrm{C}$ was higher than the other two conditions $\left(325\right.$ and $\left.350^{\circ} \mathrm{C}\right)$, but it is evident from the slope of the curves that the RA transformed very fast 

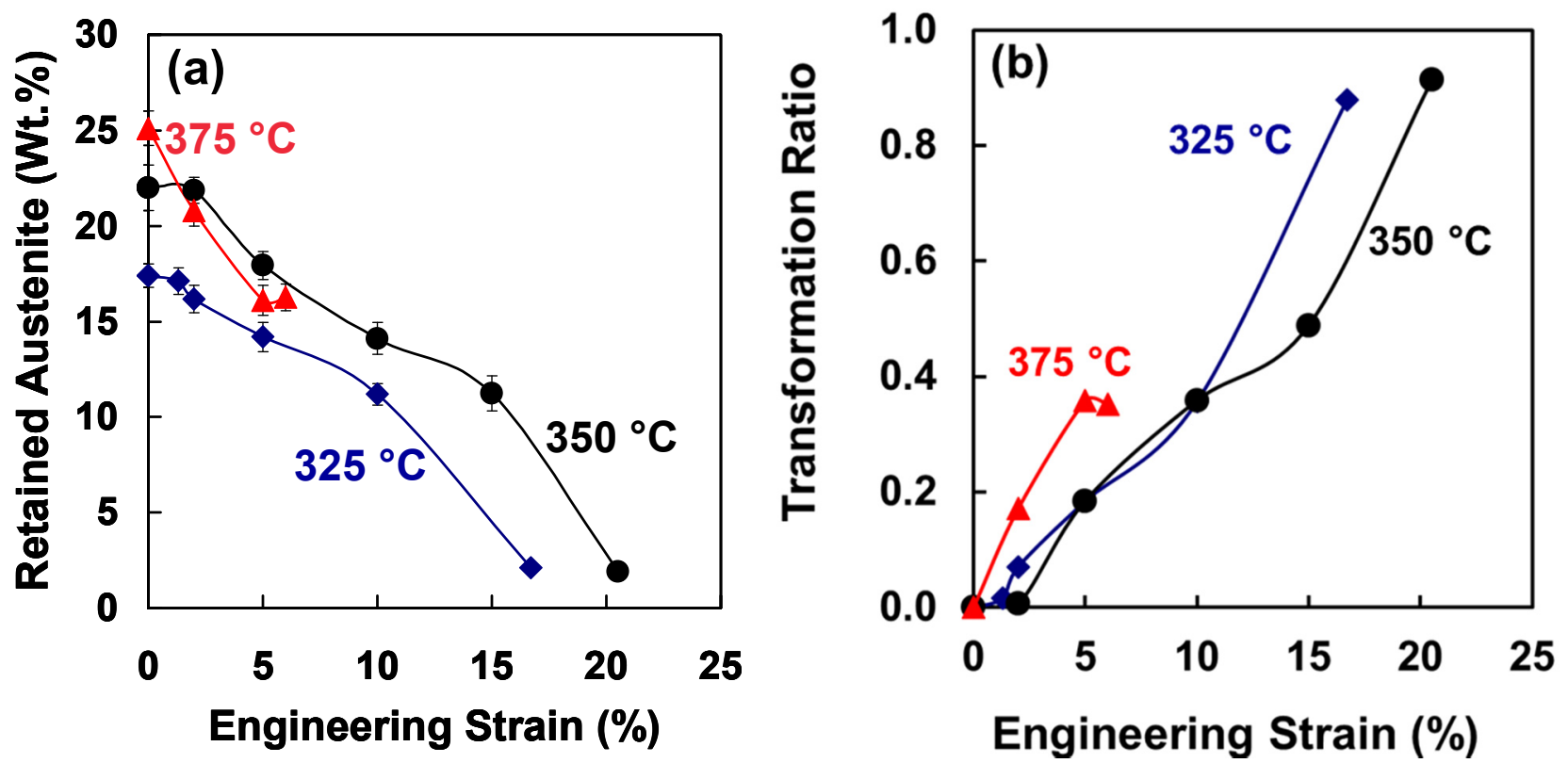

Fig. 5. Mechanical stability of retained austenite in the present steel in selected austempering conditions $\left(325,350\right.$ and $\left.375^{\circ} \mathrm{C}\right)$ determined by XRD measurements of interrupted tensile test specimens: (a) change of retained austenite with strain, and (b) austenite transformation ratio as a function of strain

with increase in strain than that in other two conditions. Furthermore, all the RA in the sample austempered at $375^{\circ} \mathrm{C}$ did not transform to martensite and premature fracture during tensile tests occurred even though the amount of untransformed RA was high. The austenite transformation ratio for a particular strain in Fig. $5 \mathrm{~b}$ is higher for the sample austempered at $375^{\circ} \mathrm{C}$ indicating a lower stability of austenite for this sample than the samples austempered at lower temperatures. The samples austempered at 325 and $350^{\circ} \mathrm{C}$ exhibited similar mechanical stability of RA up to $10 \%$ engineering strain. The lower mechanical stability of retained austenite after austempering at the higher temperature of $375^{\circ} \mathrm{C}$ could be a result of the combined effects from a coarser austenite morphology and possible carbide formation [19].

\subsection{Mechanical and formability properties}

\subsubsection{Tensile properties}

The engineering stress-strain curves of the differently heat treated samples are shown in Fig. 6a and the characteristic mechanical properties determined from the tensile curves are presented in Fig. 6b. It is clear from the tensile curves in Fig. 6a that the samples undergoing bainitic transformation in the temperature range of $300-350^{\circ} \mathrm{C}$ exhibited good combination of tensile strength and ductility whereas the samples heat treated at $375-400^{\circ} \mathrm{C}$ fractured in a brittle manner even though all the RA present in these samples was not transformed (Fig. 5a). The
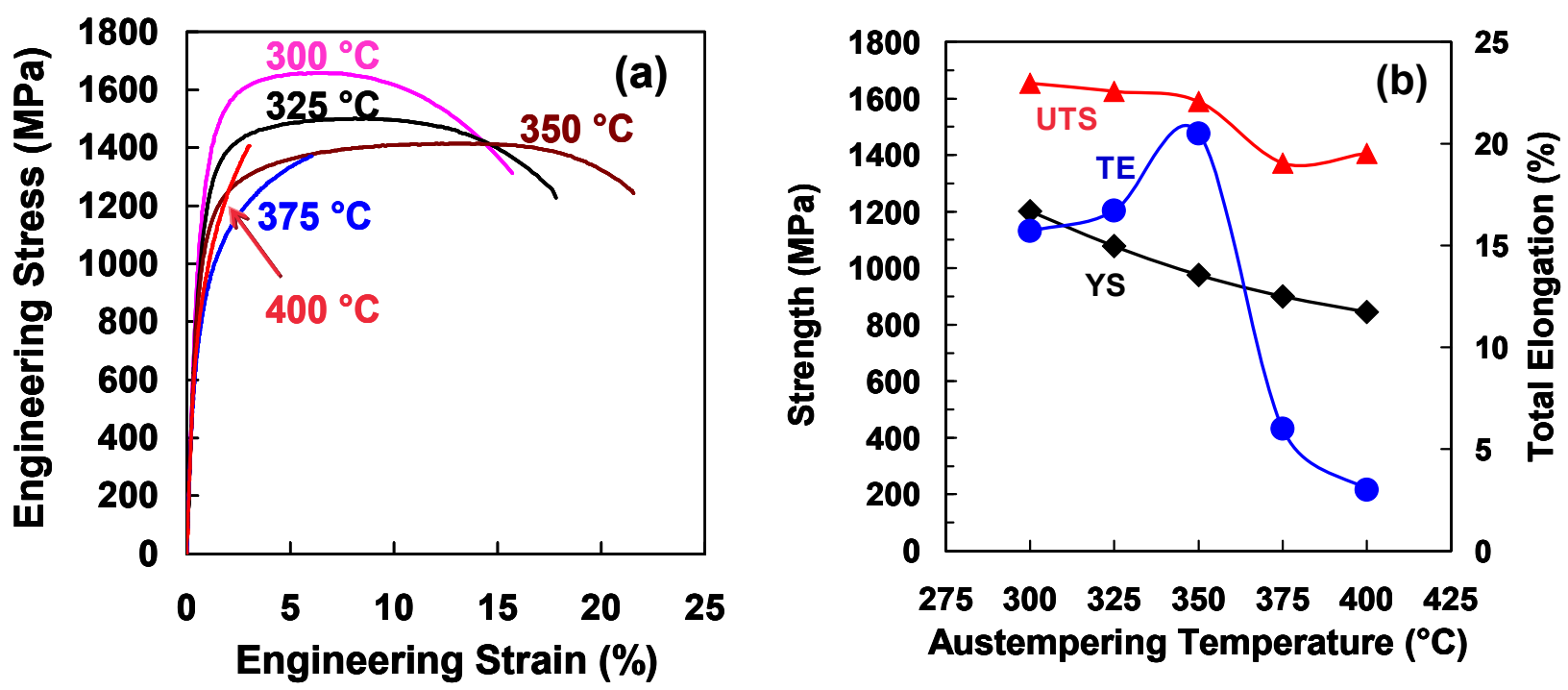

Fig. 6. Tensile data of the investigated steel for various austempering conditions: (a) the engineering stress-strain curves, and (b) tensile properties plotted against austempering temperature 
premature fracture of the samples heat treated at 375 and $400^{\circ} \mathrm{C}$ is caused by the presence of martensite in the initial microstructure (Figs. 2d,e and 4), a coarse morphology of retained austenite (Fig. 2d,e) and a relatively low mechanical stability of retained austenite (Fig. 5). The presence of initial martensite and newly transformed martensite at an early stage of deformation due to low mechanical stability of retained austenite provide areas of hard phase regions in softer bainitic ferrite matrix causing potential damage initiation sites at the interfaces of hard and soft phase regions. Therefore, avoiding martensite in the initial microstructure and increasing the mechanical stability of retained austenite appear to be necessary to achieve a good combination of mechanical properties in the current steel.

Both the yield strength (YS) and ultimate tensile strength (UTS) decreased with increasing austempering temperature (Fig. 6b) probably because of decreasing bainite content in the microstructure as can be estimated from Fig. 4. The total elongation (TE) increased initially with austempering temperature showing the maxima for $350^{\circ} \mathrm{C}$ and then decreased. The low TE values for high temperature austempering $\left(375\right.$ and $\left.400^{\circ} \mathrm{C}\right)$ are obviously connected with the premature fracture of the tensile specimens caused by presence of martensite and low mechanical stability of retained austenite.

As depicted in Fig. 7, the achieved tensile properties for low temperature austempering $\left(300-350^{\circ} \mathrm{C}\right)$ place the current steel truly in the property band of third generation advanced high strength steels (3GAHSS) in the commonly used "strengthelongation diagram" for automotive sheet steels [20]. The best combination of tensile properties was obtained for bainitic transformation at $350^{\circ} \mathrm{C}(\mathrm{UTS}=1590 \mathrm{MPa}, \mathrm{TE}=20.5 \%)$.

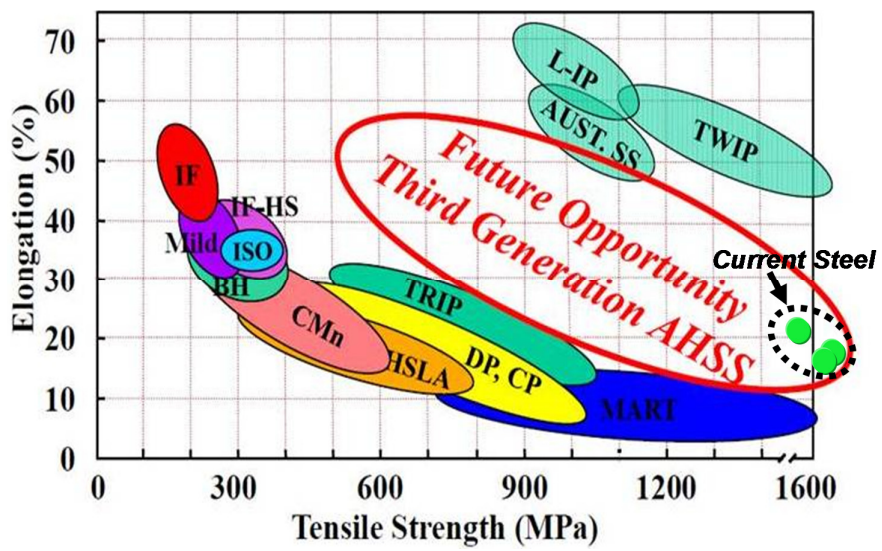

Fig. 7. The tensile strength and total elongation data of the present steel (austempered at lower temperatures of $300-350^{\circ} \mathrm{C}$ ) overlaid on the tensile-strength elongation diagram for various automotive steels [20]. The tensile properties achieved in the current bainitic steel are truly in the property band of third generation advanced high strength steels (3GAHSS)

\subsubsection{Bendability}

Bendability is an important forming parameter for automotive sheet steels as during forming of the parts as well as during a crash situation the steels sheets experience bending. The aver- age bending angles of the $3 \mathrm{~mm}$ thick steel sheets are plotted against the austempering temperature in Fig. 8 for both longitudinal and transverse specimens. The bendability of the longitudinal specimens was slightly lower than the transverse specimens because of grain orientation and possible centreline segregation in the material. The bendability was higher for austempering at lower temperatures $\left(300-350^{\circ} \mathrm{C}\right)$ yielding the highest values for $350^{\circ} \mathrm{C}$. Similar to the tensile properties, the higher bendability for lower austempering temperatures can be connected with a finer overall microstructure, absence of initial martensite and a high stability of retained austenite against deformation.

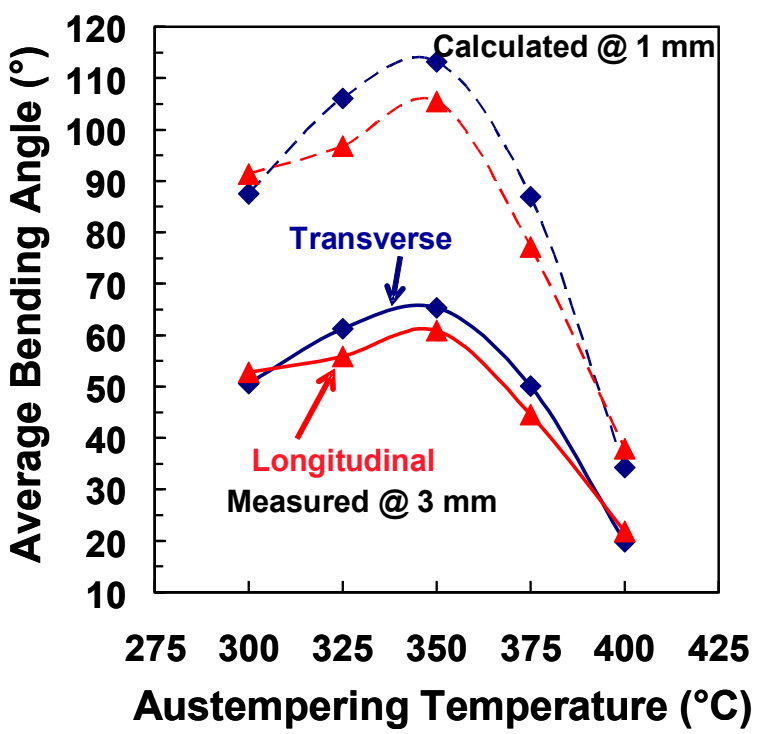

Fig. 8. Bendability, as expressed by the bending angle, of the steel with respect to the austempering temperature. Bendability is given for both longitudinal and transverse specimens; while the bending angles at $3 \mathrm{~mm}$ thickness are measured values, the ones at $1 \mathrm{~mm}$ thickness were calculated from the measured values at $3 \mathrm{~mm}$ thickness

To compare the bendability of the present $3 \mathrm{~mm}$-thick, hot rolled material with that of cold rolled steel sheets having a typical thickness of $1 \mathrm{~mm}$, the measured bending angles for $3 \mathrm{~mm}$ thickness were converted to the bending angle at $1 \mathrm{~mm}$ thickness using the following formula [21]:

$$
B_{1 \mathrm{~mm}}=B_{t} \cdot \sqrt{t}
$$

where $B_{1 \mathrm{~mm}}$ is the bending angle at $1 \mathrm{~mm}$ thickness and $B_{t}$ is the bending angle measured for thickness $t$ (in $\mathrm{mm}$ ). These calculated bending angles for $1 \mathrm{~mm}$ thickness of the sheets are also plotted in the same graph of Fig. 8 where the measured bending angles were shown. The highest bendability achieved for austempering at $350^{\circ} \mathrm{C}$ equals to a bending angle of about $100^{\circ}$ at $1 \mathrm{~mm}$ thickness. This bendability is quite high for the tensile strength level achieved in the material (1590 MPa).

\subsubsection{Flangeability}

Flangeability represents the ability of the sheared edge to bend and can also be conceived as 'sheared edge ductility' of 
sheets. It is also a very important formability parameter for cold formable automotive sheets since many sheared edges as well as holes may undergo some degree of bending during forming operation and assembling the formed parts. The HER values for different heat treatments of the present steel are plotted in Fig. 9 against the austempering temperature. The trend of variation of HER with austempering temperature leading to variations in microstructure is similar to that for tensile properties and bendability discussed earlier. The HER values are higher for low temperature austempering when retained austenite is relatively stable against deformation and no martensite is present initially in the starting microstructure. However, the optimum austempering temperature for achieving the highest HER value was found to be $325^{\circ} \mathrm{C}$ unlike $350^{\circ} \mathrm{C}$ for highest tensile ductility and bendability (Figs. 6,8). This may be related to the stability of retained austenite during hole expansion tests which is likely to induce a different state of stress than during tensile deformation or bending deformation. Almost no expansion of the punched hole (i.e. HER $\approx 0$ ) was observed for higher austempering temperatures that yielded a coarse microstructure with blocks of martensite and retained austenite of low stability (Figs. 2,4,5). It is also noteworthy that the highest HER value obtained for austempering at $325^{\circ} \mathrm{C}(\sim 28 \%)$ for an UTS level higher than $1500 \mathrm{MPa}$ is quite high when the HER value of commercialised steels at different strength levels are considered.

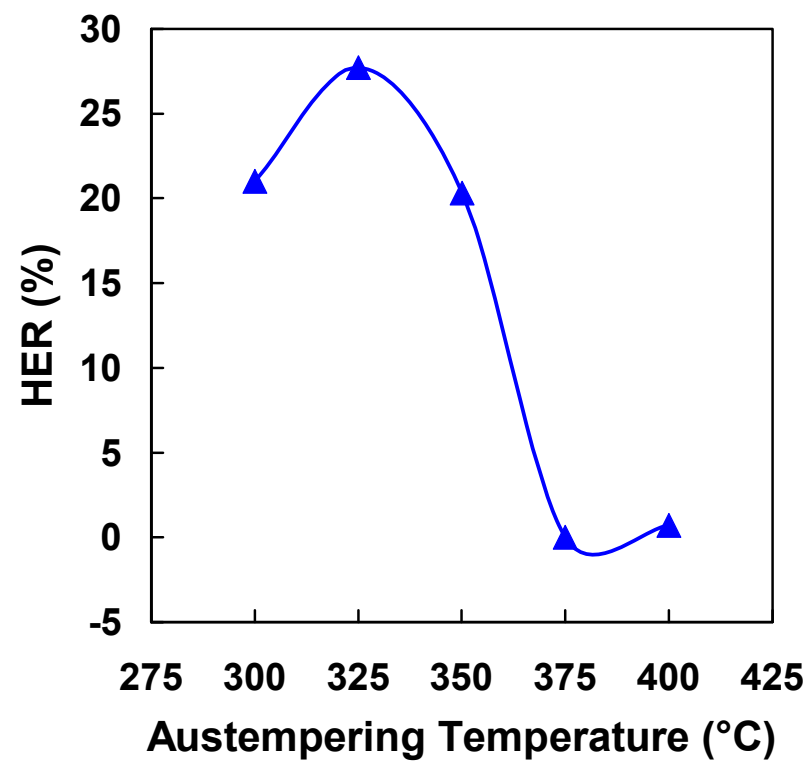

Fig. 9. Flangeability of the steel measured in terms of hole expansion ratio (HER) as a function of austempering temperature

\subsubsection{Impact Toughness}

Since the sheet steel in the current investigation is relatively thick (i.e. in hot rolled condition), impact energy absorption of the material may be of relevance in certain applications, particularly for crash resistant components. The values of the absorbed impact energy measured from Charpy specimens heat treated at 350 and $375^{\circ} \mathrm{C}$ have been plotted with respect to test temperature in Fig. 10. For both the austempering conditions, impact energy decreased with a lowering of test temperature from ambient temperature. When the energy absorption curves between the two austempering conditions are compared, austempering at $350^{\circ} \mathrm{C}$ yielded higher impact energy values than that at $375^{\circ} \mathrm{C}$. This is again connected with the stability of retained austenite for the selected two austempering conditions that was shown in Fig. 5, in addition to the effects from presence initial martensite in the microstructure. In the specimens with a higher stability of retained austenite (i.e. for austempering at $375^{\circ} \mathrm{C}$ ), the retained austenite transformed to martensite during the tests at a slower rate or incompletely leading to higher absorption of energy than in the specimens with retained austenite of lower stability.

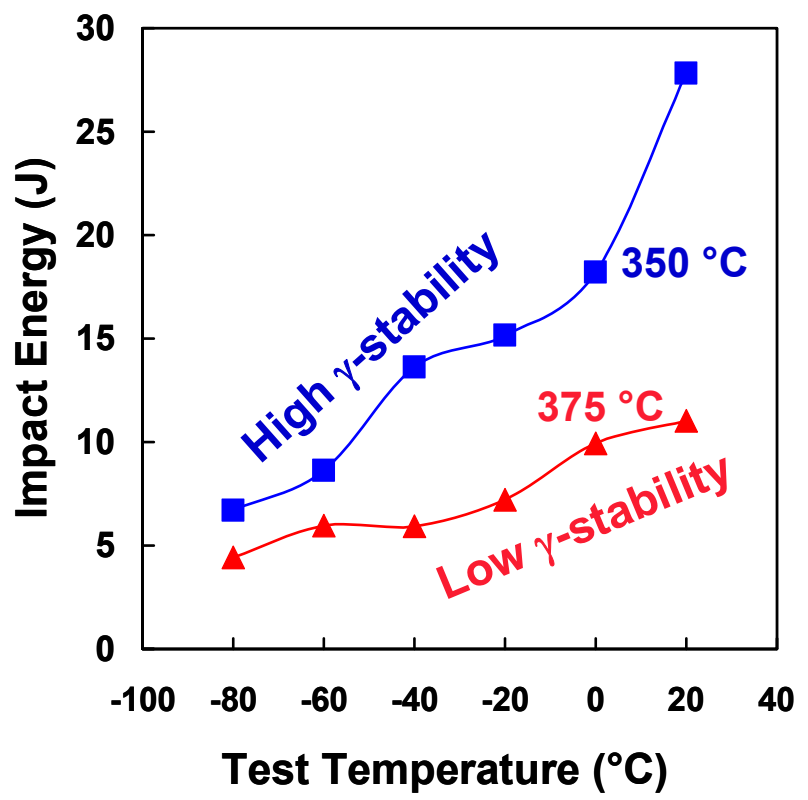

Fig. 10. Variation of impact toughness of the steel with test temperature for high and low austenite stability conditions achieved by austempering at 350 and $375^{\circ} \mathrm{C}$ respectively. The steel for Charpy impact toughness tests was prepared in laboratory by hot rolling from $80 \mathrm{~mm}$ to $12 \mathrm{~mm}$ thickness

\section{Conclusions}

Based on the present work on hot rolled bainitic steel, the following conclusions can be drawn:

- The desired microstructure of fine bainitic ferrite with high amount of retained austenite in the present steel (Fe-0.34C$2 \mathrm{Mn}-1.5 \mathrm{Si}-1 \mathrm{Cr}$, wt.\%) is producible through hot rolling route with proper alloy design,

- Good tensile properties in the property band of third generation advanced high strength steels can be achieved in the current steel,

- $\quad$ Optimum coiling temperature range for the best mechanical and formability properties of the current steel is $325-350^{\circ} \mathrm{C}$

- High stability of retained austenite, absence of initial martensite and a fine microstrcture are the key to achieving good properties in the present steel. 


\section{REFERENCES}

[1] F.G. Caballero, H.K.D.H. Bhadeshia, J.A. Mawella, D.G. Jones, P. Brown, Mater. Sci. Technol. 17, 512-516 (2001).

[2] F.G. Caballero, H.K.D.H. Bhadeshia, J.A. Mawella, D.G. Jones, P. Brown, Mater. Sci. Technol. 17, 517-522 (2001).

[3] H.K.D.H. Bhadeshia, Hard bainite, in: J.M. Howe, D.E. Laughlin, J.K. Lee, U. Dahmen, and W.A. Soffa (Eds.), Solid-Solid Phase Transformations in Inorganic Materials, 2005, TMS, Pennsylvania.

[4] V.F. Zackay, E.R. Parker, D. Fahr, R. Bush, Trans. Am. Soc. Met. 60, 252-259 (1967).

[5] H.C. Shin, T.K. Ha, Y.W. Chang, Scripta Mater. 45, 823-829 (2001)

[6] S. Zaefferer, J. Ohlert, W. Bleck, Acta Mater. 52, 2765-2778 (2004).

[7] W.C. Leslie, The Physical Metallurgy of Steels, 1983 McGraw-Hill, New York, pp. 259-263.

[8] J. Wang, P.J. van der Wolk, S. van der Zwaag, Mater. Trans. JIM 41 (7), 761-768 (2000).

[9] C. Capdevila, F.G. Caballero, and C. García de Andrés, ISIJ Inter. 42 (8), 894-902 (2002).
[10] Y-K. Lee, J. Mater. Sci. Lett. 21, 1253-1255 (2002).

[11] L.C. Chang, Metall. Mater. Trans. A 30, 909-916 (1999).

[12] S. Das, A. Haldar, Metall. Mater. Trans. A 45 (4), 1844-1854 (2014).

[13] R.A. Young, The Rietveld Method, International Union of Crystallography, Oxford University Press, Oxford, 1993.

[14] TOPAS, Total Pattern Analysis Solution, Bruker AXS GmbH, Karlsruhe, 2003-2009.

[15] H.K D.H. Bhadeshia, Metal Sci. 15, 477-479 (1981).

[16] O. Dmitrieva, D. Ponge, G. Inden, J. Millán, P. Choi, J. Sietsma, D. Raabe, Acta Mater. 59 (1), 364-374 (2011).

[17] J. Deliry, Mem. Sci. Rev. Metallurg. 62, 527-5501 (1965).

[18] H.K.D.H. Bhadeshia, Materials Science Forum 500-501, 63-74 (2005).

[19] S. Chen, R. Rana, C. Lahaije, Metall. Mater. Trans. A 45 (4), 2209-2018 (2014).

[20] R. Rana, P.J. Gibbs, E.De Moor, J.G. Speer, D.K. Matlock, Steel Research Inter. 86 (10), 1139-1150 (2015).

[21] Tata Steel Report 12345, 2000. 